\title{
Plasmid profiles of Shigella dysenteriae type 1 isolates from Ethiopia with special reference to $R$-plasmids
}

\author{
A. GEBRE-YOHANNES and B. S. DRASAR*
}

\section{Department of Microbiology, National Research Institute of Health, PO Box 1242, Addis Ababa, Ethiopia and - Department of Clinical Sciences, London School of Hygiene and Tropical Medicine, London WC1E 7HT}

\begin{abstract}
Summary. Plasmid profiles of 80 Shigella dysenteriae type 1 (Shiga's bacillus) strains, collected between 1974 and 1985 in Ethiopia, were examined. Strains with the dominant antibiotic-resistance (R-) type-resistance to ampicillin (A), chloramphenicol (C), streptomycin (S), sulphadiazine (Su) and tetracycline (T) - showed two distinct plasmid profiles (PP). Six plasmid bands were demonstrated in "Ethiopian strains" with PP-1A isolated between 1974 and 1982. In mating experiments with these strains, Escherichia coli K12 recipients showed plasmids pYH10a ( 72 Mda, atypical Inc $\mathrm{FI}_{\text {me }}$, coding for ACSSuT resistance). Eight plasmid bands were demonstrated in strains with PP-2A. These strains were first isolated in 1980 and carried plasmid pYH1la (40 Mda, Inc X, coding for ACT resistance). Strains with PP-2A were identical with a "Zairian strain" described elsewhere. Strains with Rtype ACT' were "Zairian strains" lacking the 5.1- and 4.2-Mda plasmids. Those with R-type CSSuT were temporally clustered in 1978-1980 and carried plasmid pYH12 (58 Mda, Inc B, coding for the same R-type). A trimethoprim-resistant strain (Gimira strain) had a pattern of small plasmids similar to those of the "Zairian strain" and is probably a subclone of the latter. The fact that a limited number of plasmid profiles have remained constant over many years shows the limitation of plasmid profile analysis as an epidemiological tool. However, when the usual profile is known for a given area, identification of a distinctly different pattern becomes easy and epidemiologically useful.
\end{abstract}

\section{Introduction}

Shigellosis is a major health problem in developing countries where conditions still favour endemic disease. In most of these countries there is continuous transmission with sporadic outbreaks or epidemics of serious proportions. ${ }^{1}$ The emergence of plasmid-bearing antibiotic, multi-resistant Shigella strains has been widely recognised, and has become a serious problem for chemotherapy. However, considering the magnitude of the problem, laboratory investigations of the causative shigellae have been very scanty. In Ethiopia, there have been limited reports of the prevalence of various serotypes ${ }^{2,3}$ and their resistance patterns. ${ }^{4-6}$ Reports of R-factors have appeared only recently ${ }^{7,8}$ and studies of plasmid profiles or $\mathrm{R}$ plasmid characterisation have not been done.

Within the last few years, some of the previously arcane methods of molecular biology have been

Received 16 Oct. 1989; revised version accepted 5 April 1990.

* Correspondence should be sent to Dr B. S. Drasar. simplified. It is now possible to use relatively simple, quick and inexpensive methods to prepare plasmid DNA from bacterial isolates and to visualise it after agarose gel electrophoresis. Accordingly, the molecular analysis of plasmids has been applied to the investigation of epidemiological problems. The usefulness of plasmid analysis for typing $S$. sonnei isolates was evaluated by Prado $e t$ al. ${ }^{9}$ but similar studies on the epidemiologically important $S$. dysenteriae type 1 (Shiga's bacillus) have not been reported. The purpose of this study was to analyse the plasmid patterns of $S$. dysenteriae type 1 isolates in Ethiopia, and to evaluate plasmid profiles as an epidemiological tool. An attempt was also made to characterise the R-plasmids found in these isolates.

\section{Materials and methods}

\section{Shigella strains}

A total of 133 strains of $S$. dysenteriae type 1 was isolated from 1974 to 1985 at the National Research 
Institute of Health (Addis Ababa, Ethiopia) from stools or rectal swabs of patients suffering from acute diarrhoea. The patients were from different parts of the city and had no recognised epidemiological link. Isolates were stored at $-70^{\circ} \mathrm{C}$ in trypticase soy yeast broth with glycerol $25 \%$ v/v. From this collection, 76 randomly-selected strains were used for plasmid analysis. For comparative study, four strains of Shiga's bacillus isolated from rural areas were used.

\section{Antibiotic susceptibility}

Sensitivity tests were done as described previously. ${ }^{7}$ The agents tested were: ampicillin (A); chloramphenicol (C); kanamycin (K); streptomycin (S); sulphadiazine (Su); tetracycline (T); trimethoprim (Tp). The subscript ' $i$ ' with these abbreviations refers to partial (intermediate) resistance.

\section{Plasmid extraction}

Plasmid DNA from wild-type Shiga's bacillus and $E$. coli $\mathrm{K} 12$ recipients ${ }^{10}$ was extracted according to the method of Birnboim and Doly. ${ }^{11}$ Eppendorf-type $1.5-\mathrm{ml}$ polypropylene tubes and centrifugation at $10000 \mathrm{~g}$ were used. All chemicals used were Analar grade or equivalent (BDH or Sigma). Plasmid designation was according to Novick et al. ${ }^{18}$

\section{Agarose-gel electrophoresis}

Agarose (A-6877, Sigma) was dissolved by heating in TE buffer (40mM Tris-acetate, $2 \mathrm{~mm}$ disodium EDTA, $\mathrm{pH}$ $8 \cdot 0$ ). The agarose was allowed to solidify at room temperature in a horizontal gel apparatus (BRL, Model H4). About $35 \mu$ l of plasmid DNA from strains of Shiga's bacillus or their $E$. coli $\mathrm{K} 12$ counterparts was mixed with $6 \mu$ l of tracking dye, ${ }^{12}$ bromocresol purple $0.1 \% \mathrm{w} / \mathrm{v}$ in glycerol $50 \%$, and run at a constant voltage of $150 \mathrm{~V}$ for $3.5 \mathrm{~h}$. Gels were then soaked in an aqueous solution of ethidium bromide $0.5 \mu \mathrm{g} / \mathrm{ml}$ for $1 \mathrm{~h}$. Plasmids were visualised on a Blak-Ray model 61 ultraviolet transilluminator (Ultraviolet Products, San Gabriel, USA) and photographed with an MP4 land camera (Polaroid Corporation, Cambridge, MA, USA) equipped with type 57 land film and an orange wratten filter (Eastman Kodak Co., Rochester, NY, USA). ${ }^{13}$

\section{Mol.-wt determination}

Mol. wt of plasmids in wild-type Shiga's bacillus and E. coli $\mathrm{K} 12$ recipients ${ }^{10}$ was determined in relation to the mobility of reference plasmids carried in E. coli $39 \mathrm{R} 861$ (NCTC 50192, harbouring plasmids of $98,42,23.9$ and $4 \cdot 6 \mathrm{Mda}$ ). E. coli $\mathrm{V} 517^{14}$ with plasmids of $35 \cdot 8,4 \cdot 8,3 \cdot 7$, $3.4,2.6,2.0$ and $1.8 \mathrm{Mda}$ and $E$. coli with plasmids TP 116 (143.7 Mda) and TP 124 (120 Mda) (Plasmid Reference Centre, Stanford, CA, USA) were routinely included to check the suitability of the mini-preparation of Birnboim and Doly ${ }^{11}$ for the detection of large and small plasmids. Open circular (OC) forms of plasmid DNA were identified after selective extraction at acid $\mathrm{pH}$ and low ionic strength. ${ }^{15}$

\section{$R$-plasmid incompatibility testing}

E. coli $\mathrm{K} 12$ strains carrying single plasmids and derived by mating experiments ${ }^{10}$ with Shiga's bacillus were, in turn, mated with NCTC reference strains carrying reference plasmids of the following incompatibility groups: B, C, D, FI, FII, FIII, FIV, FV/OF, $\mathrm{H}_{1}, \mathrm{H}_{2}, \mathrm{H}_{3}$, $\mathrm{I}_{1}, \mathrm{I}_{2}, \mathrm{~J}, \mathrm{~K}, \mathrm{M}, \mathrm{N}, \mathrm{P}, \mathrm{T}, \mathrm{U}, \mathrm{W}, \mathrm{X}, \mathrm{FI}_{\mathrm{me}}$ and MP10. Incompatibility testing was by the methods of Grindley et al. ${ }^{16}$ and Anderson and Threlfall. ${ }^{10}$

\section{Restriction enzyme analysis}

Purified plasmid DNA (c. 1-2 $\mu \mathrm{g}$ ) was digested with an excess of EcoRl enzyme (BRL, Cambridge). The restriction-enzyme mixture contained $50 \mathrm{mM} \mathrm{NaCl}$, $10 \mathrm{mM} \mathrm{MgCl}_{2}$ and $10 \mathrm{~mm}$ Tris- $\mathrm{HCl}, \mathrm{pH} \mathrm{7.5}$; the procedure was that of Maniatis et al. ${ }^{17}$

\section{Results}

Table I shows two main plasmid profiles (PPs) associated with the dominant R-type (ACSSuT). Six plasmid bands of $120,72,12 \cdot 5 \mathrm{OC}, 6 \cdot 0,5 \cdot 2$ and 2.4 Mda were demonstrated in strains with PP-1A. These strains were isolated between 1974 and 1982 . Eight plasmid bands of $120,40,12 \cdot 5 \mathrm{OC}, 6 \cdot 0,5 \cdot 2$, 2.4 and $1.7 \mathrm{Mda}$ were demonstrated in isolates of Shiga's bacillus with PP-2A. The strains were first isolated in 1980. Isolates of Shiga's bacillus with Rtype ACT had plasmid profiles (PP-4) similar to that of PP-2A, but lacked the 5.1- and 4.2-Mda plasmids. Those isolates with R-type CSSuT and PP-3 were temporally clustered in 1978-1980. An epidemic-associated trimethoprim-resistant strain of Shiga's bacillus (Gimira strain) showed a plasmid profile (PP-9) very similar to that of strains with PP-2A.

The mol. wts and incompatibility groups of Rplasmids associated with the plasmid profiles described above are shown in table II. Plasmid pYH10a (72 Mda, Inc FI ${ }_{\text {me }}$, coding for $\mathrm{ACS}_{\mathrm{i}} \mathrm{SuT}$ resistance) was characteristic of strains with $\mathrm{PP}-$ 1A, whereas plasmid pYH11a (40 Mda, Inc X, coding for ACT resistance) characterised strains with PP-2A. Plasmid pYH12 (58 Mda, Inc B, coding for CSSuT resistance) was associated with the plasmid profile (PP-3) of strains with R-type CSSuT. A 40-Mda, Inc X plasmid coding for TTp resistance was demonstrated in the Gimira strain (PP-9). The overall distribution of incompatibility 
grouping of R-plasmids showed that Inc $\mathrm{FI}_{\mathrm{me}}$ and Inc $X$ plasmids are common in isolates of Shiga's bacillus from Ethiopia.

An $E c o$ R1 restriction enzyme digest of plasmid pYH1 la showed fragments of $15,5 \cdot 4,5 \cdot 2,3 \cdot 4,2 \cdot 1$, $1 \cdot 7,1 \cdot 4,1.3$ and 0.9 Mda.

\section{Discussion}

In a recent paper, ${ }^{7}$ we demonstrated that there were two distinct patterns of R-plasmid transferfrequencies in strains of Shiga's bacillus with Rtype ACSSuT : the ACSSuT resistance determinant in strains isolated before 1980 transferred to $E$. coli $\mathrm{K} 12$ at low frequencies $\left(<10^{-4}\right.$ resistant progeny per recipient cell), whereas $50 \%$ of conjugative plasmids in strains isolated after 1980 transferred at very high frequencies $\left(10^{\circ}-10^{-2}\right)$ and expressed the ACT determinant only. The present study of plasmid profiles of strains of Shiga's bacillus has further clarified the difference between these two series of isolates. Strains with PP-1A carried plasmid pYH10a, which transferred at low frequencies. This strain, which we refer to as an "Ethiopian strain", was the only strain found in Ethiopia between 1974 and 1980. In an earlier report by Frost et al., ${ }^{19}$ a single isolate of Shiga's bacillus from Somalia was found to harbour an Inc $F_{\text {me }}$ plasmid coding for ACSSuT resistance along with an Inc X plasmid coding for ACT resistance.
Isolates of Shiga's bacillus with PP-2A first appeared in Ethiopia in 1980, and carried plasmid pYH11a which transferred at high frequencies. This plasmid profile ( $\mathrm{PP}-2 \mathrm{~A})$ was closely related to that of the "Zairian strain" E22106 described by Frost et al. ${ }^{20}$ The Ethiopian isolate of the "Zairian strain" harboured a conjugative plasmid (pYH11a) of which the mol. wt, resistance-phenotype and Inc group were identical to that of the $\mathrm{R}$-plasmid in strain E22106. The 40-Mda plasmid from strains isolated in Ethiopia also showed nine EcoR1generated fragments identical to those in the "Zairian strain". 20

Our study has shown that the "Zairian strain" from Ethiopia was linked to severe epidemics in parts of three administrative regions of Ethiopia: Gondar (1981), Illubabor (1983), and Hararge (1983). We presume that this represents an extension of the Central African epidemic into Ethiopia. This becomes even more plausible when we consider the fact that the Central African focus started in $1979^{20}$ and identical strains appeared in Ethiopia in 1980. The Tanzanian epidemic of 1982$1983^{21}$ is probably linked with the Central African epidemic. It would be useful to analyse representative strains of Shiga's bacillus from different African countries to see if they are genetically related.

Haider et $a l^{22}$ analysed the plasmid profiles of strains of Shiga's bacillus from different geographical locations other than Africa. The major resist-

Table I. Plasmid profile analysis of $S$. dysenteriae type 1 isolates from Addis Ababa

\begin{tabular}{|c|c|c|c|c|c|c|c|c|c|c|c|c|c|c|c|c|}
\hline \multirow{2}{*}{$\begin{array}{c}\begin{array}{c}\text { Resistance } \\
\text { type* }\end{array} \\
\text { ACSSuT }\end{array}$} & \multirow{2}{*}{$\begin{array}{c}\begin{array}{c}\text { Number of } \\
\text { isolates }\end{array} \\
112\end{array}$} & \multirow{2}{*}{$\begin{array}{c}\begin{array}{c}\text { Plasmid } \\
\text { profile }\end{array} \\
\text { PP-1A }\end{array}$} & \multirow{2}{*}{$\frac{\begin{array}{c}\text { Number of } \\
\text { isolates }\end{array}}{38}$} & \multirow{2}{*}{$\begin{array}{c}\begin{array}{c}\text { Year of } \\
\text { isolation }\end{array} \\
1974-82\end{array}$} & \multicolumn{12}{|c|}{ Plasmids (size in Mda) } \\
\hline & & & & & 120 & 72 & & $\ldots$ & $\ldots$ & $12 \cdot 5 \dagger$ & 6 & $5 \cdot 2$ & $\ldots$ & $\ldots$ & $2 \cdot 4$ & $\ldots$ \\
\hline & & PP-1B & 1 & 1979 & 120 & 72 & 57 & $\ldots$ & $\ldots$ & $12 \cdot 0$ & 6 & $5 \cdot 3$ & $\ldots$ & $\ldots$ & $2 \cdot 5$ & $\ldots$ \\
\hline & & PP-1C & 1 & 1978 & 120 & 72 & $\ldots$ & $\ldots$ & $\ldots$ & $12 \cdot 0$ & 6 & $5 \cdot 3$ & $\ldots$ & $\ldots$ & $2 \cdot 5$ & 1.9 \\
\hline & & PP-1D & 1 & 1982 & 120 & $\ldots$ & $\ldots$ & $\ldots$ & $\ldots$ & $12 \cdot 0$ & 6 & $\ldots$ & $4 \cdot 3$ & 3.0 & $2 \cdot 5$ & $\ldots$ \\
\hline & & PP-2A & 15 & $1980-84$ & 120 & $\ldots$ & $\ldots$ & 40 & $\ldots$ & $12 \cdot 5$ & 6 & $5 \cdot 1$ & $4 \cdot 2$ & $\ldots$ & $2 \cdot 4$ & $1 \cdot 7$ \\
\hline & & PP-2B & 1 & 1980 & 120 & $\ldots$ & $\ldots$ & 40 & $\ldots$ & $13 \cdot 0$ & 6 & $5 \cdot 1$ & $4 \cdot 3$ & $4 \cdot 0$ & $2 \cdot 4$ & $1 \cdot 7$ \\
\hline & & PP-2C & 1 & 1983 & 120 & $\ldots$ & 50 & $41 \cdot 5$ & $\ldots$ & $12 \cdot 5$ & 6 & $5 \cdot 1$ & $4 \cdot 3$ & $\ldots$ & $2 \cdot 5$ & 1.8 \\
\hline & & PP-2D & 1 & 1984 & 120 & 70 & $\ldots$ & 39 & $\ldots$ & $12 \cdot 5$ & 6 & $5 \cdot 1$ & $4 \cdot 2$ & $\ldots$ & $2 \cdot 4$ & $1 \cdot 7$ \\
\hline CSSuT & 9 & PP-3 & 9 & $1978-80$ & 120 & $\ldots$ & 58 & $\ldots$ & $\ldots$ & $12 \cdot 5$ & 6 & $\ldots$ & $\ldots$ & $\ldots$ & $2 \cdot 4$ & $\ldots$ \\
\hline $\mathrm{ACT}$ & 5 & PP-4 & 5 & $1982-85$ & 120 & $\ldots$ & $\ldots$ & $38 \cdot 5$ & $\ldots$ & $12 \cdot 5$ & 6 & $\ldots$ & $\ldots$ & $\ldots$ & $2 \cdot 4$ & $1 \cdot 6$ \\
\hline SSuT & 3 & PP-5A & 2 & 1982 & 120 & $\cdots$ & 60 & $\ldots$ & $\cdots$ & $12 \cdot 5$ & 6 & $\ldots$ & $\dddot{4} \cdot 2$ & $\cdots$ & 2.4 & 1.6 \\
\hline & & PP-5B & 1 & 1982 & 120 & $\ldots$ & 60 & $\ldots$ & $\ldots$ & $12 \cdot 5$ & 6 & $5 \cdot 1$ & $4 \cdot 2$ & $\ldots$ & $2 \cdot 4$ & $1 \cdot 6$ \\
\hline $\mathrm{CSSu}$ & 1 & PP-6 & 1 & 1983 & 120 & $\ldots$ & 56 & $\ldots$ & $\ldots$ & $12 \cdot 8$ & 6 & $\ldots$ & $\ldots$ & $\ldots$ & $2 \cdot 4$ & $\ldots$ \\
\hline $\mathrm{Su}$ & 1 & PP-7 & 1 & 1977 & 120 & 70 & $\ldots$ & $\ldots$ & $\ldots$ & $12 \cdot 8$ & 6 & $\ldots$ & $\ldots$ & $\ldots$ & $2 \cdot 4$ & $\ldots$ \\
\hline ACKSSuT & 1 & PP-8 & 1 & 1978 & 120 & 72 & 63 & $\ldots$ & $\ldots$ & $12 \cdot 5$ & 6 & $\ldots$ & $\ldots$ & $3 \cdot 0$ & $2 \cdot 4$ & $\ldots$ \\
\hline ACSSuTTp & 1 & PP-9§ & 1 & 1983 & 120 & $\ldots$ & $\ldots$ & 40 & 35 & $12 \cdot 5$ & 6 & $5 \cdot 1$ & $4 \cdot 3$ & $\ldots$ & $2 \cdot 5$ & $1 \cdot 7$ \\
\hline Total & 133 & $P P: 1-9$ & 80 & $1974-85$ & & & & & & & & & & & & \\
\hline
\end{tabular}

* See Materials and methods.

† The 12.5-13.0 Mda plasmid represented an open circular (OC) form.

$\ddagger$ Three isolates were from epidemics in rural Ethiopia.

$\S$ An epidemic strain from Gimira, Keffa, SW Ethiopia. 
Table II. Molecular weight and incompatibility group of R-plasmids from S. dysenteriae type 1

\begin{tabular}{|c|c|c|c|c|c|c|}
\hline $\begin{array}{l}\text { Plasmid } \\
\text { profile }\end{array}$ & $\begin{array}{l}\text { Number of } \\
\text { isolates }\end{array}$ & $\begin{array}{c}\text { Recipient } \\
\text { R-type* }\end{array}$ & $\begin{array}{l}\text { Number of } \\
\text { recipient strains }\end{array}$ & $\begin{array}{c}\text { Plasmid } \\
\text { designation }\end{array}$ & $\begin{array}{l}\text { Plasmid size } \\
\quad \text { (Mda) }\end{array}$ & $\begin{array}{c}\text { Incompatibility } \\
\text { group } \dagger\end{array}$ \\
\hline PP-1A & 38 & ACS SuT & 38 & pYH10a & 72 & $\mathrm{FI}_{\mathrm{me}}$ \\
\hline PP-1B & 1 & ACS SuT & 1 & pYH10b & 72 & $\mathrm{FI}_{\text {me }}$ \\
\hline PP-1C & 1 & $\mathrm{ACS}_{\mathrm{i}} \mathrm{SuT}$ & 1 & pYH10c & 72 & $\mathrm{FI}_{\mathrm{me}}$ \\
\hline PP-1D & 1 & ACS SuT & 1 & pYH10d & 72 & $\mathrm{FI}_{\text {me }}$ \\
\hline PP-2A & 15 & ACT & 15 & pYH1la & 40 & $\mathbf{X}$ \\
\hline PP-2B & 1 & ACT & 1 & pYH1lb & 40 & $\mathrm{x}$ \\
\hline PP-2C & 1 & $\mathrm{ACT}$ & 1 & pYH1lc & $41 \cdot 5$ & $\mathrm{x}$ \\
\hline PP-2D & 1 & $\mathrm{ACT}$ & 1 & pYH1ld & 39 & $\mathrm{x}$ \\
\hline PP-3 & 9 & CSSuT & 8 & pYH12 & $57 \cdot 5$ & B \\
\hline PP-4 & 5 & $\mathrm{ACT}$ & 5 & pYH $11 \mathrm{e}$ & 38.5 & $\mathrm{X}$ \\
\hline PP-5 & 3 & $\mathrm{~T}$ & 3 & pYH 13 & 60 & $\mathbf{N}$ \\
\hline PP-6 & 1 & $\mathrm{CSSu}$ & 1 & pYH14 & 56 & FII \\
\hline PP-7 & 1 & $\mathrm{Su}$ & 1 & pYH15 & 70 & B \\
\hline \multirow[t]{3}{*}{ PP-8 } & 1 & ACKSSuT & 1 & - & 72,63 & - \\
\hline & & $\mathrm{AK}$ & 1 & pYH16 & 63 & UNC $\ddagger$ \\
\hline & & ACS SuT & 1 & pYH $10 \mathrm{e}$ & 72 & $\mathrm{FI}_{\mathrm{me}}$ \\
\hline \multirow[t]{3}{*}{ PP-9 } & 1 & ACSSuTTp & 1 & - & $40,35,5 \cdot 1,4 \cdot 3$ & - me \\
\hline & & $\mathrm{AC}$ & 1 & pYH17 & 35 & $\mathbf{X}$ \\
\hline & & TTp & 1 & pYH 18 & 40 & $\mathrm{X}$ \\
\hline
\end{tabular}

\footnotetext{
* See Materials and methods: recipient was $E$. coli $\mathrm{K} 12, \mathrm{~F}^{-}, \mathrm{Lac}^{+}$(nalidixic acid resistant, prototrophic; Enteric Reference Laboratory no. 14R525).

$\dagger$ Inc $\mathrm{FI}_{\text {me }}$ plasmids were atypical.

$\ddagger$ Unclassified; lack of a suitable marker.
}

ance phenotypes encountered were R-types CSSuT, CSSuTTp and ACSSuTTp. The authors concluded that three plasmids of $140,6 \cdot 0$ and $2 \cdot 0$ Mda were common to all isolates of Shiga's bacillus. Our study showed that the large plasmid in Shiga's bacillus, as was reported by Frost et al., ${ }^{20}$ was typically about $120 \mathrm{Mda}$ and all of our strains carried a cryptic plasmid of about $2.4 \mathrm{Mda}$. The 6.0-Mda plasmid, mentioned above, was a constant feature of all isolates of Shiga's bacillus in Ethiopia, and is known to code for one or more functions for " $\mathrm{O}$ " antigen production and bacterial virulence. ${ }^{23}$ This plasmid was found earlier in African strains of Shiga's bacillus. ${ }^{20}$ It seems to be strongly associated with isolates of Shiga's bacillus of African and Asian origin, and is probably serotype specific (unpublished observations).

Our data show that the plasmid profile characteristic of the "Ethiopian strain" was observed over a 9-year period. The "Zairian strain" isolated in Ethiopia also had a reproducible plasmid profile between 1980 and 1984. The predominance of a given strain for a long time gives rise to the question as to whether any particular plasmid-encoded biological properties were responsible. To our knowledge, ours is the first report of isolates of Shiga's bacillus maintaining a uniform plasmid profile for about a decade. However, among the genus Salmonella, $S$. wien was reported to have maintained a uniform plasmid profile for this length of time. ${ }^{24,25}$ This Salmonella species harboured an Inc $\mathrm{FI}_{\mathrm{me}}$ plasmid, as did the Shiga's bacillus endemic in Ethiopia. However, the Inc $\mathrm{FI}_{\text {me }}$ plasmid in our isolates was atypical; it had a mol. wt of only $72 \mathrm{Mda}$ and was incompatible with Inc $\mathrm{FI}_{\text {me }}$ and MP10, but was compatible with FI. Casalino et al. ${ }^{25}$ reported the existence of natural derivatives of inc $\mathrm{FI}_{\mathrm{me}}$ plasmids of $70-80 \mathrm{Mda}$. The authors classified these atypical strains as Inc $\mathrm{FI}_{\text {me }}$ despite their compatibility with MP10.

A common pattern of cryptic plasmids in Shiga's bacillus has been demonstrated in this study and in a previous report. ${ }^{20}$ The fact that African strains of Shiga's bacillus contained significantly more plasmids than strains from Central America and Mexico ${ }^{20}$ is interesting and deserves further study. Recent reports from Asia indicate that small plasmids are ubiquitous in Shigella isolates. ${ }^{22,26}$

Isolates of Shiga's bacillus of PP-4 and R-type ACT overlapped with the appearance of the "Zairian strain" in Ethiopia. The loss of resistance of streptomycin and sulphadiazine in these strains corresponded with the loss of the $5 \cdot 1-$ and $4 \cdot 2-\mathrm{Mda}$ plasmids as detected by agarose gel electrophoresis. 
It is now well established that the $4 \cdot 2-\mathrm{Mda}$ plasmid coded for $\mathrm{SSu}$ resistance in isolates of Shiga's bacillus from Africa ${ }^{19,20}$ and so the 5.1-Mda plasmid may not be associated with SSu resistance.

Isolates of Shiga's bacillus of PP-3 and R-type CSSuT were temporally clustered in 1978-1980, and possessed plasmid pYH12 (58 Mda, Inc B). These isolates were of same R-type as those from Central America. ${ }^{1}$ However, the plasmid size in Ethiopian strains is considerably smaller than the $80-$ Mda Inc B plasmids from Central America, ${ }^{27}$ but is identical with that of Inc B plasmids from Sri-Lanka. ${ }^{20}$

Despite the wide use of trimethoprim for the treatment of enteric and other infections, Shiga's bacillus has remained almost uniformly sensitive to this drug in Ethiopia. ${ }^{4,6}$ The only strain resistant to trimethoprim in this study was the "Gimira strain" with PP-9. This epidemic strain showed the basic plasmid profile of the "Zairian strain" and was isolated when the latter had established itself in Ethiopia. It is most likely that the "Gimira strain" is a subclone of the "Zairian strain".

The single isolate of Shiga's bacillus with trans-

\section{REFERENCES}

1. Mata LJ, Gangarosa EJ, Caceres A, Perera DR, Mejicanos ML. Epidemic Shiga bacillus dysentery in Central America. I. Etiologic investigations in Guatemala, 1969. J Infect Dis 1970; 122: 170-180.

2. Gebre-Yohannes A, Habte-Gabr E. Shigellosis in Ethiopia. I. Prevalent Shigella serogroups and serotypes. $J$ Diarrhoeal Dis Res 1984; 2 : 79-82.

3. Gebre-Yohannes A, Drasar BS. Shigella dysenteriae and Sh. flexneri: serotype prevalence and seasonal distribution in Addis Ababa, Ethiopia (1978-85). Ethiop J Hlth Dev $1987 ; 2: 51-58$.

4. Gebre-Yohannes A, Limenih Y. Multiple drug resistance within Shigella serogroups. Ethiop Med J 1980; 18: 714.

5. Gedebou M, Tassew A. Shigella species from Addis Ababa: frequency of isolation and in vitro drug sensitivity. $J$ Hyg (Camb) 1982;88:47-55.

6. Gebre-Yohannes A. Habte-Gabr E. Shigellosis in Ethiopia. II. Patterns of drug resistance in Shigella serotypes. $J$ Diarrhoeal Dis Res 1984; 2: 212-215.

7. Gebre-Yohannes A, Drasar BS. Transferable or mobilisable antibiotic resistance in Shigella dysenteriae types 1,2 , $3,4,6$ and 7 isolated in Ethiopia during 1974-85. J Med Microbiol 1988; 27 : 285-289.

8. Gebre-Yohannes A, Drasar BS, Plasmid mediated drug resistance in Shigella flexneri serotypes 1-6 during 1974-85. Indian J Med Red 1988; 88: 480-487.

9. Prado D, Murray BE, Clearly TG, Pickering LK. Limitations of using the plasmid pattern as an epidemiological tool for clinical isolates of Shigella sonnei. J Infect Dis 1987 ; 155 : $314-316$.

10. Anderson ES, Threlfall EJ. The characterization of plasmids ferable $\mathrm{Su}$ resistance carried a $70-\mathrm{Mda}$ Inc $\mathrm{B}$ plasmid (PP-7). Davey and Pittard ${ }^{28}$ analysed five Shigella strains harbouring transferable plasmids of 42-59 Mda coding for sulphonamide resistance. By contrast, the non-conjugative sulphonamideresistance plasmids have been reported to be of 3.5-3.9 Mda. $^{29}$

The above discussion clearly illustrates the clonal nature of isolates of Shiga's bacillus from Ethiopia. The fact that the plasmid profile in Shiga's bacillus has remained constant over many years limits the usefulness of plasmid profiles for epidemiological investigation. However, when the usual profile is known for a given area, identification of a different pattern, as has been demonstrated in this study, becomes easy and epidemiologically useful.

Equipment and consumable items used in this study were generously funded by the World Health Organization. Financial assistance from the National Research Institute of Health (Ethiopia) is gratefully acknowledged. The authors thank Drs B. Rowe and E.J. Threlfall for their help and advice in the project and Dr D.M. Minter for providing photographic equipment. We are also grateful to Dr E.M. Lederberg for useful advice on plasmid nomenclature and to $\mathrm{Dr} M$. Valvano for plasmid-carrying reference strains.

in the Enterobacteria. J. Hyg (Camb) 1974; 72: 471487.

11. Birnboim HC, Doly J. A rapid alkaline extraction procedure for screening recombinant plasmid DNA. Nucleic Acids Res 1979; 7: 1513-1523.

12. Takahashi S, Nagano Y. Rapid procedure for isolation of plasmid DNA and application to epidemiological analysis. J Clin Microbiol 1984; 20 : 608-613.

13. Kopecko DJ, Washington O, Formal SB. Genetic and physical evidence for plasmid control of Shigella sonnei form I cell surface antigen. Infect Immun 1980; 29 : 207 214.

14. Marcina FL, Kopecko DJ, Jones KR, Ayers DJ, McCowen SM. A multiple plasmid-containing Escherichia coli strain: convenient source of size reference plasmid molecules. Plasmid 1978; 1 : 417-420.

15. Zasloff M, Ginder GD, Felsenfeld G. A new method for the purification and identification of covalently closed circular DNA molecules. Nucleic Acids Res 1978; 5: 1139-1152.

16. Grindley NDF, Grindley JN, Anderson ES. R factor compatibility groups. Mol Gen Genet 1972; 119: 287297.

17. Maniatis T, Fritsch EF, Sambrook J. Molecular cloning: a laboratory manual. Cold Spring Harbour, NY, Cold Spring Harbour Laboratory. 1982; 104-106.

18. Novick RP, Clowes RC, Cohen SN, Curtiss R, Datta N, Falkow S. Uniform nomenclature for bacterial plasmids: a proposal. Bacteriol Rev 1976; 40: 168-189.

19. Frost JA, Rowe B, Vandepitte J, Threlfall EJ. Plasmid characterization in the investigation of an epidemic caused by multiply resistant Shigella dysenteriae type 1 in Central Africa. Lancet 1981 ; 1 : 1074-1076.

20. Frost JA, Willshaw GA, Barclay EA, Rowe B. Plasmid characterization of drug-resistant Shigella dysenteriae 1 
from an epidemic in Central Africa. J Hyg (Camb) $1985 ; 94: 163-172$.

21. World Health Organization. Guidelines for the control of epidemics due to Shigella dysenteriae 1. Geneva, WHO; Document WHO/CDD/SER/88.12. 1988: 4.

22. Haider K, Kay BA, Talukder KA, Hug MI. Plasmid analysis of Shigella dysenteriae type 1 isolates obtained from widely scattered geographical locations. J Clin Microbiol 1988; 26: 2083-2086.

23. Watanabe H, Timmis KN. A small plasmid in Shigella dysenteriael specifies one or more functions essential for $\mathrm{O}$ antigen production and bacterial virulence. Infect Immun 1984; 43: 391-396.

24. McConnell MM, Smith HR, Leonardopoulos J, Anderson ES. The value of plasmid studies in the epidemiology of infections due to drug-resistant Salmonella wien. $J$ Infect Dis 1979; 139: 178-190.

25. Casalino $\mathbf{M}$, Comanduci $A$, Nicoletti $M$, Maimone $F$.
Stability of plasmid content in Salmonella wien in late phases of the epidemic history. Antimicrob Agents Chemother 1984; 25: 499-501.

26. Arai T, Sasahira T, Sakaguchi T et al. Plasmid DNA survey of clinically isolated Shigella strains in Shanghai area. Chin Med J 1988; 101: 346-352.

27. Crosa JH, Olarte J, Mata LJ, Luttrop LK, Panaranda ME. Characterization of an R-plasmid associated with ampicillin resistance in Shigella dysenteriae type 1 from epidemics. Antimicrob Agents Chemother 1977; 11 : 553558.

28. Davey RB, Pittard J. Genetic and biophysical study of Rplasmids conferring sulphonamide resistance in Shigella strains isolated in 1952 and 1956. J Bacteriol 1974; 120: 1186-1195.

29. Mitsuhashi S, Inoue $K$, Inoue $M$. Nonconjugative plasmids encoding sulfanilamide resistance. Antimicrob Agents Chemother 1977 ; 12 : 418-422. 